\title{
PERALIHAN HAK ATAS TANAH DAN BANGUNAN TERHADAP JUAL BELI YANG DILAKUKAN DI BAWAH TANGAN DENGAN JAMINAN KREDIT PEMILIKAN RUMAH
}

\author{
Ny. Ayni Suwarni Herry \\ Universitas Pamulang \\ e-mail : doseno0707@unpam.ac.id
}

\begin{abstract}
In carrying out buying and selling transactions conducted by the community is one of the procedures for a person in obtaining ownership rights over land and buildings. Buying and selling agreements, is the type of agreement most often done by the community from the past until until now. In providing services to the public, a PPAT is tasked with serving requests to make certain land deeds referred to in regulations relating to land registration and PPAT Position regulations. In dealing with these requests, PPAT must make a decision to reject or grant the relevant request. PPAT as a public official, the deed he made was given the position as an authentic deed, that is a deed made to prove the existence of certain legal actions that resulted in the transfer of rights to land and buildings. The existence of a PPAT deed that intends to make a deed of agreement for the transfer of land rights and ownership rights to a unit of flats through the sale and purchase, exchange, grants, income in companies and other legal acts of transfer of rights, except the transfer of rights due to an auction which can only be registered if proven by a deed made by the authorized PPAT and if the deed of transfer of land rights and ownership rights to the said flats unit has been registered by the Head of the Land Office in the land book register.
\end{abstract}

Keywords: Agreement, Sale and Purchase, Authentic Deed

\begin{abstract}
Abstrak
Dalam melaksanakan transaksi jual beli yang dilakukan oleh masyarakat merupakan salah satu tata cara seseorang dalam memperoleh hak kepemilikan atas tanah dan bangunan. Perjanjian jual beli, merupakan jenis perjanjian yang paling banyak dilakukan oleh masyarakat dari sejak dulu hingga sampai pada saat ini. Dalam memberi pelayanan kepada masyarakat seorang PPAT bertugas untuk melayani permohonan-permohonan untuk membuat akta-akta tanah tertentu yang disebut dalam peraturan-peraturan berkenaan dengan pendaftaran tanah serta peraturan Jabatan PPAT. Dalam menghadapi permohonan-permohonan tersebut PPAT wajib mengambil keputusan untuk menolak atau mengabulkan permohonan yang bersangkutan. PPAT sebagai pejabat umum, maka akta yang dibuatnya diberi kedudukan sebagai akta otentik, yaitu akta yang dibuat untuk membuktikan adanya perbuatan hukum tertentu yang mengakibatkan terjadinya peralihan hak atas tanah dan bangunan. Adanya akta PPAT yang bermaksud membuat akta perjanjian pengalihan hak atas tanah dan hak milik atas satuan rumah susun melalui jual beli, penukaran, hibah, pemasukan dalam perusahaan dan perbuatan hukum pemindahan hak lainnya, kecuali pemindahan hak karena lelang yang hanya dapat didaftarkan jika dibuktikan dengan akta yang dibuat oleh PPAT yang berwenang dan jika akta peralihan hak atas tanah dan hak milik atas satuan rumah susun tersebut sudah didaftarkan oleh Kepala Kantor Pertanahan dalam daftar buku tanah.
\end{abstract}

Kata kunci: Perjanjian, Jual Beli, Akta Otentik 


\section{PENDAHULUAN}

Dewasa ini begitu banyak pembangunan property di daerah-daerah perkotaan, pinggiran perkotaan bahkan hingga ke pedesaan yakni guna memenuhi kebutuhan manusia atas tempat tinggal idaman yang layak untuk berlindung. Pesatnya perkembangan pembangunan tersebut, membuat setiap manusia ingin memiliki tempat tinggal idaman mereka masing-masing.

Dalam kehidupan bermasyarakat yang diliputi oleh adat kebiasaan, tanpa kita sadari banyak peristiwa-peristiwa hukum yang terjadi sehari-hari yang dibuktikan dengan persaksian. Biasanya orang-orang yang menjadi saksi hidup untuk peristiwaperistiwa tersebut adalah tetangga-tetangga, teman-teman, atau perangkat desa. Peristiwa-peristiwa tersebut dapat berupa perkawinan atau peristiwa yang memiliki akibat hukum yang penting seperti jual beli atau sewa menyewa tanah. Namun demikian dalam persaksian terdapat kelemahan antara lain apabila pada saat dibutuhkan kesaksiannya, ternyata saksi yang bersangkutan telah meninggal dunia (Notodisoerjo, 1982: 5).

Untuk menghindari serta meminimalkan terjadinya permasalahan tersebut, seseorang membutuhkan suatu alat bukti guna membuktikan hak-haknya dan/atau kewajiban-kewajibannya atas orang lain. Dalam Kitab Undang-Undang Hukum Perdata yang sering juga disebut KUHPer atau BW (Burgerlijk Wetboek), sebagaimana dalam pasal 1867 Kitab Undang-Undang Hukum Perdata Buku Keempat mengenai Pembuktian dan Daluarsa dijelaskan bahwa pembuktian dengan tulisan dapat dilakukan dengan tulisan otentik atau dengan tulisan dibawah tangan. Yang dimaksud dengan tulisan otentik atau yang sering juga disebut dengan akta otentik adalah suatu akta yang dibuat dalam bentuk yang telah ditentukan oleh Undang-Undang dan dibuat oleh atau dihadapan pejabat umum yang berwenang untuk itu di mana akta dibuat.

Pasal 1458, Kitab Undang-Undang Hukum Perdata menyebutkan bahwa "Jual beli dianggap telah terjadi antara kedua belah pihak, segera setelah orang-orang ini mencapai kesepakatan tentang barang tersebut beserta harganya, meskipun barang itu belum diserahkan dan harganya belum dibayar."

Artinya adalah bahwa perjanjian jual beli tersebut baru menyatakan hak dan kewajiban para pihak saja, tetapi belum terjadi peralihan hak atas tanah dan bangunan yang menjadi obyek jual beli tersebut. Kemudian agar terjadinya peralihan hak maka diperlukan adanya suatu penyerahan secara yuridis. Apabila memperhatikan isi dari perjanjian yang diatur Kitab Undang-Undang Hukum Perdata sebagian besar adalah perjanjian yang bebas bentuk, dalam pengartian perjanjian tersebut dapat dilakukan oleh para pihak baik secara lisan maupun tulisan, baik berupa surat dibawah tangan maupun akta otentik yang dibuat dihadapan pejabat yang berwenang yakni Pejabat Pembuat Akta Tanah (PPAT). Salah satu perjanjian yang sering dilakukan oleh masyarakat di Indonesia adalah perjanjian peralihan hak atas tanah.

Jual beli merupakan salah satu cara peralihan hak atas tanah, dimana tanah sebagai obyek hukum kebendaan yang telah diatur secara khusus dalam beberapa peraturan perundang-undangan di negara Indonesia, sehingga segala perbuatan hukum yang berhubungan dengan tanah akan terikat oleh peraturan perundang-undangan tersebut. Hal ini berarti semua pihak yang akan melakukan perbuatan atau tindakan hukum tertentu pada hak atas tanah, tidak dibebaskan dalam pelaksanakannya karena terikat oleh peraturan perundang-undangan tersebut.

Dengan adanya peraturan perundangundangan itu, maka seluruh perbuatan hukum tentang peralihan hak atas tanah 
tidak mudah dilaksanakan hingga ada beberapa yang mengakibatkan banyak kesulitan bagi masyarakat, khususnya masyarakat awam yang cenderung kurang memiliki pemahaman mengenai hukum serta peraturan perundang-undangan. Karena hingga saat ini masih banyak ditemui permasalahan tentang praktek jual beli dengan obyek hak atas tanah yang dilakukan dengan akta dibawah tangan, ada juga yang dilakukan hanya dengan membuat kuitansi atas pembayaran obyek hak atas tanah saja.

Hal ini tentunya mengakibatkan kesulitan bagi pihak pembeli, karena pada saat pihak pembeli ingin melaksanakan pendaftaran peralihan hak atas tanahnya pada Kantor Pertanahan setempat, namun Kantor Pertanahan menolak permohonan atas pendaftaran peralihan hak atas tanah karena dilakukan secara dibawah tangan dan tidak dibuat dihadapan pejabat yang berwenang.

Jual beli atas hak atas tanah harus dilaksanakan dihadapan Pejabat yang berwenang, dalam hal ini adalah Pejabat Pembuat Akta Tanah yang wilayah kerjanya meliputi wilayah obyek atas tanah tersebut berada (Pasal 37 Peraturan Pemerintah Nomor 24 tahun 1997 tentang Pendaftaran Tanah dan Pasal 1 Peraturan Pemerintah Nomor 37 tahun 1998 tentang Peraturan Jabatan Pejabat Pembuat Akta Tanah).

Beberapa hal yang perlu dan harus untuk diperhatikan sebelum melaksanakan jual beli hak atas tanah, antara lain :

1. Status kepemilikan hak atas tanah tersebut (bukti kepemilikan hak atas tanah masih berupa hak milik adat atau sudah bersertifikat).

2. Apakah hak atas tanah tersebut sedang menjadi agunan di Bank?

Apabila obyek hak atas tanah masih dalam status agunan di Bank, maka dapat disimpulkan bahwa tanah dan bangunan yang berada diatas obyek hak atas tanah tersebut didapat oleh pihak Debitur melalui fasilitas Kredit Kepemilikan Rumah dari Bank yang bersangkutan. Sehingga selama kredit belum dilunasi, pihak Debitur tidak diperkenankan untuk mengalihkan obyek hak atas tanahnya kepada pihak-pihak lain.

Jika hal tersebut dilanggar oleh Debitur karena sesuatu hal hingga dengan terpaksa hendak mengalihkan hak atas tanah kepada pihak ketiga, yang dimana pihak ketiga ini mengetahui bahwa Debitur masih belum melunasi cicilannya, maka biasanya mereka melakukan suatu perjanjian jual beli obyek hak atas tanah secara dibawah tangan baik dengan bukti bukti tertulis berupa akta perjanjian dibawah tangan atau dapat pula dengan berupa selembar kuitansi sebagai bukti pembayaran obyek hak atas tanah tersebut.

Dalam ketentuan hukum yang sebenarnya, semestinya jual beli tersebut dilaporkan kepada Bank selaku pemberi kredit kepada Debitur sehingga dapat dilaksanakan proses alih Debitur. Akan tetapi biasanya para pihak tidak melaksanakan ketentuan tersebut dengan alasan bahwa mereka akan mengalami prosedur-prosedur yang berbelit-belit. Dan kemudian setelah semua kewajiban Debitur (selaku Penjual) telah dilunasi kepada Bank, maka Pihak ketiga (selaku Pembeli) akan mengalami berbagai permasalahan. Pertama yaitu tidak dapat mengambil asli surat-surat tanah yang tersimpan di Bank karena asli surat-surat kepemilikan hak atas tanah (sertifikat dan dokumen-dokumen lainnya) masih terdaftar atas nama Debitur (selaku Penjual). Kedua yaitu masalah yang sering terjadi saat ini adalah Debitur (selaku Penjual) tidak diketahui lagi keberadaannya setelah terjadinya transaksi jual beli obyek hak atas tanah dengan pihak ketiga. Sehingga Pihak Penjual tidak dapat ikut serta menandatangani Akta Jual Beli yang dibuat dihadapan Pejabat Pembuat Akta Tanah (PPAT). Ketiga adalah karena tanpa adanya Akta Jual Beli yang dibuat dihadapan Pejabat Pembuat Akta Tanah 
(PPAT) maka kepala Kantor Pertanahan sangat jelas akan menolak untuk melakukan pencatatan peralihan haknya dengan dasar Peraturan Pemerintah Pasal 45 Nomor 24 tahun 1997.

Karena dalam hal ini akta jual beli obyek hak atas tanah yang dibuat dihadapan Pejabat Pembuata Akta Tanah (PPAT) berfungsi sebagai alat bukti beralihnya hak atas tanah untuk keperluan pendaftaran atas nama pihak ketiga (selaku Pembeli) sebagai pemegang hak terakhir. Akta jual beli tidak dapat dibuat oleh Pejabat Pembuat Akta Tanah (PPAT) apabila persyaratan administrasi tidak dilengkapi oleh Pihak Penjual ataupun Pihak Pembeli. Dan dalam kasus penulisan ini adalah Pihak Penjual (selaku pemegang hak lama) tidak diketahui lagi tempat tinggal dan keberadaannya. Karena kesulitan tersebutlah, sehingga Pejabat Pembuat Akta Tanah (PPAT) menyarankan kepada Pihak Pembeli untuk memohon Pengadilan Negeri mengeluarkan putusan mengenai kepemilikan hak atas tanah dan bangunan yang dimaksud.

Dalam Pasal 1867 Kitab UndangUndang Hukum Perdata menyatakan bahwa "pembuktian dengan tulisan dilakukan dengan tulisan otentik maupun tulisan dibawah tangan.” Tulisan dibawah tangan ini dibuat dengan tujuan untuk dijadikan bukti tentang suatu peristiwa hukum (perjanjian). Pasal 1874 Kitab Undang-Undang Hukum Perdata diberikan pengertian tentang surat di bawah tangan yaitu surat-surat atau tulisan-tulisan yang ditandatangani dan dibuat dengan sengaja untuk menjadi bukti dari suatu peristiwa hukum tanpa melalui seorang pejabat umum (Soepomo, Hukum Acara Perdata Pengadilan Negeri, 1972 : 88).

Sedangkan Peraturan Pemerintah Pasal 37 Nomor 24 Tahun 1997 tentang Pendaftaran Tanah dan Pasal 1 Peraturan Pemerintah Nomor 37 Tahun 1998 tentang Peraturan Jabatan Pembuat Akta Tanah tersebut diatas dimana pelaksanaan jual beli hak atas tanah harus dilaksanakan dihadapan pejabat yang berwenang. Hal ini menjadi permasalahan, ketika adat kebiasaan masyarakat melaksanakan jual beli dibawah tangan dengan hanya dibuktikan kuitansi.

\section{METODE PENELITIAN}

Metode penulisan yang digunakan adalah metode penelitian kepustakaan yang bersifat yuridis normatif, dimana cara pengumpulan data yang bahan utamanya berupa peraturan-peraturan perundangundangan, makalah-makalah dan hasil dari penelitian yang telah dilakukan terdahulu berkaitan dengan peralihan hak atas tanah yang dilakukan secara dibawah tangan. Data yang dikumpulkan berupa data sekunder, yakni bahan untuk mengadakan penilaian terhadap hasil-hasil penelitian yang dilakukan peneliti sebelum melakukan penelitian yang sesungguhnya. Dengan demikian, maka penelitian yang sesungguhnya akan dapat dilakukan atas dasar ilmiah yang lebih kuat lagi (Mamudji, 2013:35).

Sedangkan penelitian yang dilakukan adalah penelitian deskriptif analistis dimana penulis bermaksud unuk memberikan gambaran mengenai suatu keadaan berdasarkan analisa-analisa yang dilakukan oleh penulis. Khususnya gambaran tentang Putusan Pengadilan yang dapat mensahkan surat perjanjian dibawah tangan dan kuitansi sebagai dasar di ijinkannya Pihak Pembeli untuk melakukan proses jual beli dihadapan Pejabat Pembuat Akta Tanah sehingga sertifikat hak atas tanah dapat didaftarkan peralihan haknya pada Kantor Badan Pertanahan setempat.

\section{PERMASALAHAN}

Penulis akan mencoba untuk merumuskan permasalahan-permasalahan yang akan dibahas oleh penulis dalam tulisan ini. Ruang lingkup dalam permasalahan 
penjualan dibawah tangan ini adalah bahwa pembeli telah membeli secara dibawah tangan (yang dibuktikan dengan kuitansi pembayaran) hak pemilikan atas tanah dan bangunan, dimana obyek atas tanah dan bangunan tersebut sedang menjadi agunan Kredit Pemilikan Rumah, sehingga prosedur pelaksanaan peralihan hak pemilikannya harus dilakukan dengan ketentuan yang berlaku di Indonesia.

Dari uraian diatas terdapat beberapa permasalahan yang dapat ditarik, yaitu :

1. Bagaimanakah prosedur peralihan hak pemilikan tanah dan bangunan atas pembelian dibawah tangan obyek tanah dan bangunan yang sedang dijaminkan di bank?

2. Bagaimana peranan Putusan Pengadilan Negeri dapat digunakan sebagai dasar pembuatan Akta Jual Beli di hadapan Pejabat Pembuat Akta Tanah?

\section{PEMBAHASAN}

Prosedur peralihan hak pemilikan tanah dan bangunan atas pembelian dibawah tangan obyek tanah dan bangunan yang sedang dijaminkan di bank

Menurut Pasal 37 ayat 1 Peraturan Pemerintah No. 24 Tahun 1997, ditegaskan bahwa:

Peralihan hak atas tanah dan hak milik atas satuan rumah susun melalui jual beli, tukar menukar, hibah, pemasukan data perusahaan dan perbuatan hukum pemindahan hak lainnya, kecuali pemindahan hak melalui lelang hanya dapat didaftarkan jika dibuktikan dengan akta yang dibuat oleh PPAT yang berwenang menurut ketentuan peraturan perundangundangan yang berlaku.

Pembuktian bahwa hak atas tanah tersebut dialihkan, maka harus dibuktikan dengan suatu akta yang dibuat oleh dan dihadapan PPAT yaitu akta jual beli yang kemudian akan dijadikan dasar pendaftaran perubahan data pendaftaran tanah sebagaimana dimaksud dalam ketentuan Pasal 95 ayat 1 huruf a Peraturan Menteri Agraria/Kepala Badan Pertanahan Nasional Nomor 3 Tahun 1997. Akta Jual Beli yang dibuat dihadapan PPAT tersebut bertujuan untuk memberikan kepastian hukum kepada pemegang hak atas suatu bidang tanah (pembeli tanah) (Adiwinata, l980 : 21-30).

Keberadaan pejabat dalam suatu tatanan ketatanegaraan sangat dibutuhkan, karena pejabat merupakan pelaksana dari pelambangan Negara yang telah disumpah untuk melaksanakan fungsinya. Negara dalam suatu konsep ketatanegaraan dalam menjalankan fungsinya diwakili oleh Pemerintah. Pemerintah dalam menjalankan fungsinya dan tugasnya dalam merealisasikan tujuan Negara diwakili oleh pejabat. Oleh karena itu, sukses tidaknya sebuah lembaga negara ditentukan oleh kemampuan pejabatnya dalam menjalankan roda Pemerintahan. Salah satu tugas pejabat, khususnya PPAT, keberadaannya diakui oleh peraturan perundang-undangan yang berlaku, yaitu Peraturan Pemerintah Nomor 24 Tahun 1997 tentang Pendaftaran Tanah jo Peraturan Pemerintah Nomor 37 Tahun 1998 tentang Peraturan Jabatan Pejabat Pembuat Akta Tanah. Hal ini merupakan konsekuensi ketentuan Pasal 1 ayat 3 Undang-Undang Dasar 1945, amandemen ke tiga 3, yang menentukan secara tegas bahwa Negara Indonesia adalah Negara hukum.

Prinsip Negara hukum menjamin kepastian, ketertiban, dan perlindungan hukum yang berintikan kebenaran dan keadilan. Kepastian, ketertiban, dan perlindungan hukum menuntut bahwa lalu lintas hukum dalam kehidupan masyarakat memerlukan adanya alat bukti yang menentukan dengan jelas hak dan kewajiban seseorang sebagai subjek hukum dalam masyarakat (Supriadi, $2006: 170$ ).

Perbuatan hukum yang dilakukan dihadapan PPAT maka akan lahir akta otentik yang akan dijadikan sebagai alat bukti bagi para pihak telah dilakukan 
perbuatan hukum tertentu mengenai hak atas tanah atau hak milik atas satuan rumah susun, yang akan dijadikan sebagai dasar bagi pendaftaran perubahan data pendaftaran tanah yang diakibatkan oleh perbuatan hukum dimaksud.

Selain dibuat dihadapan pejabat umum, untuk dapat memperoleh otentisitasnya maka akta yang bersangkutan harus dibuat dalam bentuk yang ditentukan oleh peraturan perundang-undang dan pejabat umum dihadapan siapa akta itu dibuat harus mempunyai wewenang untuk membuat akta itu, ditempat dimana akta itu dibuatnya .

Pembuatan akta PPAT menurut Pasal 24 Peraturan Pemerintah Nomor 37 Tahun 1998, ditegaskan bahwa: "ketentuanketentuan lebih lanjut mengenai tata cara pembuatan akta PPAT diatur dalam peraturan perundang-undangan mengenai pendaftaran tanah”. Berdasarkan ketentuan dalam Pasal 96 Peraturan Menteri Agraria Kepala Badan Pertanahan Nasional Nomor 3 Tahun 1997, disebutkan bahwa akta PPAT harus mempergunakan formulir atau blanko sesuai dengan bentuk yang telah disediakan dan cara pengisiannya adalah sebagaimana tercantum dalam lampiran 16 sampai dengan 23 peraturan Menteri Negara Agraria/Kepala Badan Pertanahan Nasional tersebut.

Mengenai syarat bahwa akta itu harus dibuat oleh pejabat umum yang mempunyai kewenangan untuk membuat akta, ditegaskan dalam Pasal 4 ayat 1 Peraturan Pemerintah No. 37 Tahun 1998 yang menyatakan: "PPAT hanya berwenang membuat akta mengenai hak atas tanah atau hak milik atas satuan rumah susun yang terletak di dalam daerah kerjanya”. Pada saat penandatanganan akta jual beli dilakukan, terlebih dahulu blanko akta jual beli tersebut diisi dengan nama PPAT berikut dengan saksi-saksi dari PPAT yang daerah kerjanya meliputi daerah di mana obyek hak atas tanah tersebut berada, serta telah nama para pihak, objek jual belinya berdasarkan dokumen-dokumen dan datadata yang telah disampaikan oleh para pihak. Akta tersebut kemudian oleh PPAT dibacakan kepada para pihak dan selanjutnya setelah para pihak telah mengerti akan isi dalam akta jual beli tersebut, maka para pihak menandatangani akte jual beli tersebut, kemudian oleh saksi-saksi dan PPAT (Hasil wawancara dengan Desra Natasha Warganegara,SH,M.Kn, Pejabat Pembuat Akta Tanah Kota Tangerang Selatan, pada tanggal 14 Mei 2015.).

Dalam proses pembuatan akta jual beli yang dibuat dihadapan PPAT, dibutuhkan langkah-langkah yang harus dilalui oleh PPAT sebelum dilakukan penandatanganan akta jual belinya oleh para pihak yang berkepentingan. Langkah-langkah tersebut adalah:

1. Sebelum melaksanakan pembuatan akta mengenai pemindahan atau pembebanan hak atas tanah atau Hak Milik Atas Satuan Rumah Susun, PPAT wajib terlebih dahulu melakukan pemeriksaan pada Kantor Pertanahan mengenai kesesuaian sertipikat hak atas tanah atau Hak Milik Atas Satuan Rumah Susun yang bersangkutan dengan daftardaftar yang ada di Kantor Pertanahan setempat dengan memperlihatkan sertipikat asli.

2. Akta harus mempergunakan formulir yang telah ditentukan.

3. Dalam hal diperlukan izin untuk peralihan hak tersebut, maka izin tersebut harus sudah diperoleh sebelum akta dibuat.

4. Sebelum dibuat akta mengenai pemindahan hak atas tanah, calon penerima hak harus membuat pernyataan yang menyatakan:

a. Bahwa yang bersangkutan dengan pemindahan hak tersebut tidak menjadi pemegang hak atas tanah yang melebihi 
ketentuan

penguasaan

ketentuan

perundang-undangan yang

berlaku;

b. Bahwa yang bersangkutan dengan pemindahan hak tersebut tidak menjadi pemegang hak atas tanah absentee (guntai) menurut ketentuan peraturan perundang-undangan yang berlaku

c. Bahwa yang bersangkutan menyadari bahwa apabila pernyataan sebagaimana dimaksud pada a dan b tersebut tidak benar maka tanah kelebihan atau tanah absentee tersebut menjadi obyek landreform

d. bahwa yang bersangkutan bersedia menanggung semua akibat hukumnya, apabila pernyataan sebagaimana dimaksud pada a dan b tidak benar.

5. Pembuatan akta PPAT harus dihadiri oleh para pihak yang melakukan perbuatan hukum atau orang yang dikuasakan olehnya dengan surat kuasa tertulis sesuai dengan peraturan perundangundangan yang berlaku.

6. Pembuatan akta PPAT harus disaksikan oleh sekurang-kurangnya 2 (dua) orang saksi yang menurut ketentuan peraturan perundangundangan yang berlaku memenuhi syarat untuk bertindak sebagai saksi dalam suatu perbuatan hukum, yang memberi kesaksian antara lain mengenai kehadiran para pihak atau kuasanya, keberadaan dokumendokumen yang ditunjukkan dalam pembuatan akta, dan telah dilaksanakannya perbuatan hukum tersebut oleh para pihak yang bersangkutan.

7. PPAT wajib membacakan akta kepada para pihak yang bersangkutan dan memberi penjelasan mengenai isi dan maksud pembuatan akta, dan prosedur pendaftaran yang harus dilaksanakan selanjutnya sesuai ketentuan yang berlaku.

8. Akta PPAT harus dibacakan/dijelaskan isinya kepada para pihak dengan dihadiri oleh sekurang-kurangnya 2 (dua) orang saksi sebelum ditandatangani seketika itu juga oleh para pihak, saksi-saksi dan PPAT.

9. Selambat-lambatnya 7 (tujuh) hari kerja sejak tanggal ditandatanganinya akta yang bersangkutan, PPAT wajib menyampaikan akta yang dibuatkannya berikut dokumendokumen yang bersangkutan kepada Kantor Pertanahan untuk didaftar.

Terhadap perbuatan hukum pengalihan hak tersebut, maka "PPAT wajib menyampaikan pemberitahuan tertulis mengenai telah disampaikannya akta sebagai mana dimaksud di atas kepada para pihak yang bersangkutan".

\section{Peranan Putusan Pengadilan Negeri Dapat Digunakan Sebagai Dasar Pembuatan Akta Jual Beli Dihadapan Pejabat Pembuat Akta Tanah.}

Sejak berlakunya UUPA pada tanggal 24 September 1960, ada hal-hal yang merupakan pembaharuan hukum di Indonesia bukan saja di bidang pertanahan tetapi di lain-lain bidang hukum positip. UUPA diumumkan didalam Lembaran Negara Republik Indonesia Tahun 1960 Nomor 104, yang penjelasannya dimuat didalam Tambahan Lembaran Negara Republik Indonesia nomor 2043.

Lahirnya UUPA maka dihapuskanlah 
dasar-dasar dan peraturan-peraturan hukum agraria kolonial yang sejak Indonesia merdeka masih tetap berlaku karena Indonesia belum mempunyai hukum agraria nasional, dan juga dualisme hak atas tanah dihapuskan menjadi satu sistem hukum, yaitu sistem hukum hak atas tanah di Indonesia berdasarkan hukum adat, sehingga tidak lagi diadakan perbedaan atas tanah-tanah hak adat seperti tanah hak ulayat, gogolan, bengkok dan lain-lain, maupun tanah-tanah hak barat, seperti tanah hak Eigendom, Erfpachtt, Opstal dan lain-lain,

1. Hak eingendom, adalah hak untuk membuat suatu barang secara leluasa dan untuk berbuat terhadap barang itu secara bebas sepenuhnya, asalkan tidak bertentangan dengan undang-undang atau peraturan umum yang ditetapkan oleh kuasa yang berwenang dan asal tidak mengganggu hak-hak orang lain.

2. Hak opstal, adalah hak kebendaan untuk memiliki bangunan dan tanaman-tanaman di atas sebidang tanah orang lain (Pasal $711 \mathrm{KUH}$ Perdata). 7 Hak opstal dapat dikonversi menjadi hak guna bangunan.

3. Hak erfpach, adalah hak untuk memetik kenikmatan seluas-luasnya dari tanah milik orang lain dan mengusahakannya untuk waktu yang sangat lama (Pasal $820 \mathrm{KUH}$ Perdata).

dimana tanah hak barat tersebut harus dikonversi menjadi hak-hak bentuk baru yang diatur dalam UUPA. Diketahui tanahtanah hak barat tersebut terdaftar pada Kantor Pendaftaran Tanah menurut Overschrijvingsordonnantie (Ordonantie Balik Nama Stbl.1834 No.27) dan peraturan mengenai kadaster.

Untuk merealisasikan tujuan tersebut, kegiatan pendaftaran tanah menjadi sangat penting dan mutlak untuk dilaksanakan, hal ini sesuai dengan ketentuan Pasal 19 UUPA yang menghendaki diselenggarakannya pendaftaran hak atas tanah di Indonesia. Pengaturan mengenai pendaftaran tanah diselenggarakan dengan berpedoman pada Peraturan Pemerintah Nomor 24 Tahun 1997.

Dalam pencatatan data yuridis ini khususnya pencatatan perubahan data yang sudah tercatat sebelumnya maka peranan PPAT sangatlah penting. PPAT sebagai pejabat umum yang diberi wewenang untuk membuat akta-akta dalam peralihan hak atas tanah, akta pembebanan serta surat kuasa pembebanan hak tanggungan, juga bertugas membantu Kepala Kantor Pertanahan Nasional dalam melaksanakan pendaftaran tanah dengan membuat akta-akta tertentu sebagai bukti telah dilakukannya perbuatan hukum tertentu mengenai hak atas tanah dan atau bangunan yang akan dijadikan dasar bagi bukti pendaftaran tanah (Hasil wawancara dengan Desra Natasha Warganegara,SH,M.Kn, Pejabat Pembuat Akta Tanah Kota Tangerang Selatan, pada tanggal 13 Mei 2015).

Akta PPAT merupakan salah satu sumber utama dalam rangka pemeliharaan pendaftaran tanah di Indonesia. PPAT sudah dikenal sejak berlakunya Peraturan Pemerintah Nomor 10 Tahun 1961 tentang Pendaftaran Tanah, yang merupakan peraturan tanah sebagai pelaksana UUPA.

Mengingat pentingnya fungsi PPAT perlu kiranya diadakan peraturan tersendiri yang mengatur tentang PPAT sebagaimana yang ditetapkan dalam Pasal 7 ayat 3 Peraturan Pemerintah Nomor 24 Tahun 1997, demikian juga setelah dikeluarkannya Peraturan Pemerintah Nomor 37 Tahun 1998 tentang Peraturan Pejabat Pembuat Akta Tanah. Berdasarkan Pasal 1 angka 1 Peraturan Pemerintah Nomor 37 Tahun 1998 dikatakan PPAT adalah "pejabat umum yang diberi kewenangan untuk membuat akta-akta otentik mengenai perbuatan hukum tertentu mengenai hak atas tanah atau hak atas 
satuan rumah susun".

Berdasarkan pasal tersebut diatas, maka pada dasarnya kewenangan PPAT berkaitan erat dengan perbuatan hukum tertentu mengenai hak atas tanah atau hak milik atas satuan rumah susun. Untuk membuktikan adanya perbuatan hukum pengalihan hak atas tanah dan atau bangunan haruslah dibuat akta otentik. Tanpa adanya akta otentik maka secara hukum perbuatan hukum untuk mengalihkan suatu hak atas tanah dan bangunan belum sah.

Mengenai fungsi akta PPAT dalam jual beli, Mahkamah Agung dalam Putusannya No. 1363/K/Sip/1997 berpendapat bahwa Pasal 19 Peraturan Pemerintah Nomor 10 Tahun 1961 secara jelas menentukan bahwa akta PPAT hanyalah suatu alat bukti dan tidak menyebut bahwa akta itu adalah syarat mutlak tentang sah tidaknya suatu jual beli tanah. Menurut Boedi Harsono, akta PPAT berfungsi sebagai alat pembuktian mengenai benar sudah dilakukannya jual beli. Jual beli tersebut masih dapat dibuktikan dengan alat pembuktian yang lain. Akan tetapi, dalam sistem pendaftaran tanah menurut peraturan yang telah disempurnakan yaitu Peraturan Pemerintah Nomor 24 Tahun 1997, pendaftaran jual beli hanya dapat dilakukan dengan akta PPAT sebagai alat bukti yang sah. Orang yang melakukan jual beli tanpa dibuktikan dengan akta PPAT tidak akan dapat memperoleh sertifikat, biarpun jual belinya sah menurut hukum.

Dalam memberi pelayanan kepada masyarakat seorang PPAT bertugas untuk melayani permohonan-permohonan untuk membuat akta-akta tanah tertentu yang disebut dalam peraturan-peraturan berkenaan dengan pendaftaran tanah serta peraturan Jabatan PPAT. Dalam menghadapi permohonan-permohonan tersebut PPAT wajib mengambil keputusan untuk menolak atau mengabulkan permohonan yang bersangkutan. PPAT sebagai pejabat umum, maka akta yang dibuatnya diberi kedudukan sebagai akta otentik, yaitu akta yang dibuat untuk membuktikan adanya perbuatan hukum tertentu yang mengakibatkan terjadinya peralihan hak atas tanah dan bangunan.

Adanya akta PPAT yang bermaksud membuat akta perjanjian pengalihan hak atas tanah dan hak milik atas satuan rumah susun melalui jual beli, penukaran, hibah, pemasukan dalam perusahaan dan perbuatan hukum pemindahan hak lainnya, kecuali pemindahan hak karena lelang yang hanya dapat didaftarkan jika dibuktikan dengan akta yang dibuat oleh PPAT yang berwenang dan jika akta peralihan hak atas tanah dan hak milik atas satuan rumah susun tersebut sudah didaftarkan oleh Kepala Kantor Pertanahan dalam daftar buku tanah, maka kepala Kantor Pertanahan memberikan sertipikat hak atas tanah atau hak milik atas satuan rumah susun yang bersangkutan kepada pembeli

\section{PENUTUP \\ Kesimpulan}

Prosedur peralihan hak pemilikan tanah dan bangunan atas pembelian dibawah tangan obyek tanah dan bangunan yang sedang dijaminkan di bank. Penyelesaian hukum terhadap transaksi jual beli tanah melalui over kredit yang dilakukan secara dibawah tangan dimana penjualnya sudah tidak diketahui lagi alamat atau domisilinya dapat dilakukan dengan mengajukan gugatan ke Pengadilan Negeri setempat agar jual beli yang telah dilangsungkan dapat disahkan, agar si pembeli dapat mengambil jaminan di Bank pemberi kredit dan si pembeli diberi ijin dan kuasa bertindak untuk dan atas nama penjual selaku penjual dan bertindak untuk diri sendiri selaku pembeli menghadap kepada Pejabat Pembuat Akta Tanah (PPAT) untuk menandatangani Akta Jual Beli. Peranan Putusan Pengadilan Negeri dapat digunakan sebagai dasar pembuatan Akta Jual Beli di hadapan Pejabat Pembuat Akta Tanah adalah putusan pengadilan yang berkekuatan 
hukum tetap dijadikan sebagai dasar hukum untuk membuat Akta Jual Beli. Putusan pengadilan sebagai dasar oleh pembeli untuk menandatangani akta jual beli dihadapan PPAT, hal ini sebagaimana ternyata dalam putusan pengadilan negeri yang memutuskan memberi ijin dan kuasa kepada

\section{Saran}

Agar instansi-instansi yang terkait melaksanakan sosialiasi hukum agar masyarakat memahami tentang pentingnya peralihan hak atas tanah dilakukan dihadapan pejabat yang berwenang bukan menurut kebiasaan atau pun dengan menggunakan kwitansi, sehingga dasar pengajuan pendaftaran hak/permohonan hak atau pun sebagai dasar untuk mengalihkannya kepada pihak lain khususnya terhadap tanah-tanah yang sedang menjadi agunan kredit agar tidak menimbulkan konsekuensi yang dapat merugikan masyarakat itu sendiri dan masyarakat lain di kemudian hari. Diharapkan agar pelaksanaan over kredit dari debitur lama (selaku penjual) ke debitur baru (selaku pembeli) dilakukan secara resmi, yaitu pengalihan debitur dengan sepengetahuan dari pihak bank. Sebaiknya para debitur berkonsultasi/menghubungi pihak Bank untuk meminta persetujuan secara resmi sebelum melakukan over kredit, agar hak dan kewajiban masingmasing pihak terjamin secara hukum.

\section{DAFTAR PUSTAKA}

A. Yudha Heraoko, Kumpulan Artikel Hukum Kontrak Dan Hukum Jaminan, Surabaya, Universitas Airlangga, 2002

Adrian Sutedi, Peralihan Hak Atas Tanah dan Pendaftarannya, Jakarta, Sinar Grafika, 2006

Alfitra, Hukum Pembuktian Dalam Beracara Pidana, Perdata Dan
Korupsi di Indonesia, Jakarta, Raih Asa Sukses, 2012

Boedi Harsono, Hukum Agraria Indonesia, Sejarah Pembentukan UndangUndang Pokok Agraria, Isi Dan Pelaksanaannya, Djambatan

H. Salim HS, Perkembangan Hukum Jaminan Di Indinesia, Jakarta, Raja Grafindo Persada, 2004

J. Satrio, Hukum Jaminan, Hak Jaminan Kebendaan, Hak Tanggungan, Bandung, Citra Aditya Bakti, 1998

K. Watjik Saleh, Hak Anda Atas Tanah, Jakarta, Ghalia Indonesia, 1976

Kartini Muljadi, Gunawan Widjaja, Jual Beli, Jakarta, Raja Grafindo Perkasa, 2003

M. Bahsan, Hukum Jaminan Dan Jaminan Kredit Perbankan Indonesia, Jakarta, Raja Grafindo, 2007

Mudjiono, Politik Dan Hukum Agraria, Yogyakarta, Liberty, 1997

R. Soegondo Notodisoerjo, Hukum Nasional Di Indonesia, Jakarta, Rajawali, 1982

Sahat HMT Sinaga, Jual Beli Tanah Dan Pencatatan Peralihan Hak, Bekasi, Pustaka Sutra, 2007

Soepomo, Hukum Acara Perdata Pengadilan Negeri, Jakarta, 1972

SoerjonoSoekanto, Sri Mamudji, Penelitian Hukum Normatif Suatu Tinjauan Singkat, Jakarta, Raja Grafindo Persada, 2013

Supriadi, Hukum Agraria, Jakarta, Sinar Grafika, 2006

Wirahadi Prasetyono, Cara Mudah Mengurus Surat Tanah Dan Rumah, Yogyakarta, Flashbook, 2000 
